\title{
Pattern of Perioperative Antibiotic Use in Otorhino- laryngology-Head and Neck Surgery at Third Referral Hospital In Surabaya
}

\author{
Nabilah Puspa Utami ${ }^{1}$, Dyah Fauziah ${ }^{2}$, Muhtarum Yusuf ${ }^{3 *}$ \\ ${ }^{1}$ Faculty of Medicine, Universitas Airlangga, Surabaya, Indonesia \\ ${ }^{2}$ Department of Patology Anatomy, Faculty of Medicine, Universitas Airlangga - Dr.Soetomo General Hospital, Surabaya, \\ Indonesia \\ ${ }^{3}$ Department of Otorhinolaryngology-Head and Neck Surgery, Faculty of Medicine, Universitas Airlangga - Dr. Soetomo \\ General Hospital, Surabaya, Indonesia
}

\section{A R T I C L E I N F O}

\section{Article history:}

Received 15 May 2020

Received in revised form 03 June 2020

Accepted 08 June 2020

Available online 30 June 2020

\section{Keywords:}

Perioperative antibiotic,

ENT,

Surgery.

*) Corresponding author: muhtarumyusuf@yahoo.id

\begin{abstract}
A B S T RA C T
Introduction: Surgical site infection (SSI) often occurs in operation. SSI frequently only affects the superficial tissues, but some more serious infections can affect the deeper tissues or other parts of the body. The majority of SSIs become apparent within 30 days of an operative procedure, when a prosthetic implant is used, SSI may occur several months after the operation. To minimize surgical site infection occurrence, prophylaxis antibiotic is often used. The aim of the study is to evaluate the use of perioperative antibiotics for otorhinolaryngology surgery in third referral hospital in Surabaya. Methods: This study was a retrospective cross-sectional method through the medical record of patients cases from December 2017 to January 2018 . All data about sex, age, diagnosis, wound classification, surgical intervention including ICD $9 \mathrm{CM}$ codes, and antibiotics regiments are presented descriptively. Results: Of total 68 patients, $42(61.8 \%)$ were male and $46(61.8 \%)$ were aged 18-65 years old. The most common type of operation was clean surgery $52(76.5 \%)$. The most common prophylactic antibiotic was cefazoline $25(96.6 \%)$.

Conclusion: Most of the performed surgery was clean surgery. The use of perioperative antibiotics in most performed operations was in accordance with existing literature. The most widely used prophylactic and therapeutic antibiotic was cefazoline and ceftriaxone, respectively. Further research about risk factor of SSI, the use of prophylaxis antibiotic, and bacterial profile with more samples is needed for more accurate results.
\end{abstract}

\section{Introduction}

Epidemiological studies of surgical site infection (SSI) are complicated due to the heterogeneous nature of infection, the incidence varies greatly between procedures, hospitals, surgeons and patients. ${ }^{1}$ SSIs are defined as infections occurring within 30 days after a surgical operation (or within one year if an implant is left in place after the procedure) and affecting either the incision or deep tissue at the operation site. ${ }^{2}$ Surgical wound infection is second most common nosocomial infections after urinary tract infections. ${ }^{3}$ Surgical infections are also frequent, incidence varies from 0.5 to $15 \%$ depending on the type of surgery and the status of the underlying patient. ${ }^{3}$ In Indonesia, based on a research at Dr. Mohammad Hoesin Hospital (RSMH) in Palembang, the incidence of surgical wound infection was $56.67 \%$ of 30 patients. ${ }^{4}$ In Surabaya, based on a research at Dr. Soetomo General Hospital in Department of Obstetrics and Gynaecology, the incidence of surgical wound infection was $2.52 \%$ of 52 patients. ${ }^{5}$ In the United States, $38 \%$ of all nosocomial infections are SSI. WHO survey shows that the incidence of SSI in the world ranges from $5 \%$ to $34 \%$. SSI in the United Kingdom is around $10 \%$ with the cost to handle it reaching 1 million pounds per year and length of stay increased by 7-10 days. About $77 \%$ of postoperative patient deaths in hospitals worldwide are estimated to be related to $\mathrm{SSI}^{6}$

SSI forms the basis of the operation category. The categories of operations based on SSI are divided into clean surgery, clean-contaminated surgery, contaminated surgery, and dirty surgery. Clean surgery is an incision in which no inflammation is encountered in a surgical procedure, without a break in sterile technique, and during which the respiratory, alimentary, and genitourinary tracts are not entered. Clean-contaminated surgery is an incision through which the respiratory, alimentary, or genitourinary 
tract is entered under controlled conditions with no contamination encountered. Contaminated surgery is an incision undertaken during an operation in which there is a major break in sterile technique or gross spillage from the gastrointestinal tract or an incision in which acute, non-purulent inflammation is encountered. Open traumatic wounds that are more than 12-24 hours old also fall into this category. Dirty or infected surgery is an incision undertaken during an operation in which the viscera are perforated or when acute inflammation with pus is encountered during the operation (for example, emergency surgery for fecal peritonitis), and for traumatic wounds where treatment is delayed, and there is fecal contamination or devitalized tissue present. ${ }^{7}$

Antibiotics are drugs that can kill or inhibit the development of bacteria and other organisms. The choice of antibiotic type must be based on information about the infectious germ spectrum and the pattern of germ sensitivity to antibiotics, microbiological examination results or estimates of infectious germs, antibiotic pharmacokinetic and pharmacodynamic profiles, de-escalating after considering the microbiological results and the clinical condition of the patient and the availability of drugs, and cost effective (drugs are selected on the $b$ sis of the most cost effective and safe). ${ }^{8}$ The excessive use of antibiotics can lead to antibiotic resistance. Based on the exciting report, antibiotic-resistant bacteria species increase every year. Antibiotic-resistant bacteria and fungi cause a lot of infection cases. ${ }^{9}$

Prophylaxis antibiotic is a brief course of antibiotics administered at the start of surgery. It is widely used to minimize surgical site infection. Even in clean operations, prophylaxis antibiotic has been used to empirically reduce the bacterial burden of intraoperative contamination. The routine use of prophylaxis antibiotics, however, may have adverse effects in addition to the increased purchase and administration costs. These include not only reactions to administered drugs, such as allergic reactions, bone marrow suppression, and liver dysfunction, but less obvious complications, such as Clostridium difficile colitis that can result in the need for further antimicrobial treatment and prolong hospital stays. Even worse for the community, prophylaxis antibiotic use may induce the development of drug-resistant bacteria too. Therefore, it is preferable to avoid the routine use of prophylaxis antibiotics and to reduce its use unless complications due to infections are expected to increase. The need for prophylaxis antibiotics generally depends on the surgical wound classification, which represents the anticipated amount of bacteria at the surgical procedure site. $^{10}$

\section{Methods}

This is a cross-sectional retrospective study focuses on perioperative antibiotics use in Department of Otorhinolaryngology-Head and Neck Surgery, Dr. Soetomo General Hospital Surabaya. Furthermore, this study also assessed the suitability between the use of perioperative antibiotics regiments with surgery, ICD 9 CM code, diagnosis, and type of surgery based on existing literature.11 This study utilized all medical records from during 1 December 2017 to 31 January 2018. Data about sex, age, diagnosis, wound classification, surgical intervention including ICD 9 $\mathrm{CM}$ codes, and antibiotics regiments were extracted, while incomplete medical records were excluded. Data then processed using Microsoft Excel. This study has ben approved by Health Research and Ethics Committee Dr. Soetomo General Hospital Surabaya with approval number 0577 / KEPK / IX / 2018.

\section{Results}

Out of 102 medical records, 68 medical records were included. From total 68 patients, $42(61.8 \%)$ were male and $46(67.6 \%)$ in group age of 18-65 years old with mean age $41.68+21.894$ years (Table 1$)$.

Table 1. Demographic data

\begin{tabular}{lc}
\hline \multicolumn{1}{c}{ Characteristic } & n (\%) \\
\hline Sex & \\
Male & $42(61.8 \%)$ \\
Female & $26(38.2 \%)$ \\
\hline Age & \\
$<18$ years old & $13(19.1 \%)$ \\
$18-65$ years old & $46(67.6 \%)$ \\
$>65$ years old & $9(13.2 \%)$ \\
\hline
\end{tabular}

Based on the wound classification, out of 68 cases, the most cases were classified as clean surgery $(n=52$, $76.5 \%$ ) (Table 2)

Table 2. Surgery classification

\begin{tabular}{lll}
\hline Surgery classification & Frequency & Percent \\
\hline Clean & 52 & 76.5 \\
\hline Clean-contaminated & 16 & 23.5 \\
\hline
\end{tabular}

Based on the data (Table 3), the most performed surgical intervention was microlaryngeal surgery $(n=15,22.06 \%)$. Total of 29 surgeries (42.6\%) used antibiotic prophylaxis. The most widely used antibiotic was cefazoline $(96.6 \%)$, while the remaining unknown types of antibiotics were used (3.4\%). In several surgical intervention, such as Meatus Acusticus Externus (MAE) granulation extraction/cholesteatosis, esophagoscopy + extraction (III) with code diagnosis D13.0, mastoidectomy (III), multiple biopsy incision (III), myringoplasty/tympanoplasty with the ICD9 CM code 18.6 , and one lateral rhinotomy + medial maxillectomy case, prophylactic antibiotic was not used because the patient had been given previous therapeutic antibiotic. The use of therapeutic antibiotics was found in $13.2 \%$ of surgery. The most widely used type of therapeutic antibiotic was ceftriaxone (100\%). Meanwhile, several surgical interventions did not use prophylaxis antibiotic like adenotonsillectomy, narcose excision biopsy, microlaryngeal surgery, and grommet insertion (III). 
Table 3. The use of antibiotic based on surgical intervention

\begin{tabular}{|c|c|c|c|c|c|c|c|c|c|}
\hline \multirow{2}{*}{$\begin{array}{c}\text { Surgical } \\
\text { intervention }\end{array}$} & \multirow{2}{*}{$\begin{array}{c}\text { ICD } 9 \\
\text { CM }\end{array}$} & \multirow{2}{*}{ Dx } & \multirow{2}{*}{$\begin{array}{c}\text { Wound } \\
\text { classification }\end{array}$} & \multirow{2}{*}{ (n) } & \multicolumn{2}{|c|}{ Perioperative antibiotic } & \multirow{2}{*}{$\begin{array}{c}\text { No } \\
\text { antibiotic }\end{array}$} & \multirow[t]{2}{*}{ Prophylactic } & \multirow{2}{*}{$\begin{array}{c}\text { Therapeutic } \\
\text { antibiotic }\end{array}$} \\
\hline & & & & & Prophylactic & Therapeutic & & & \\
\hline \multirow{3}{*}{ Adenotonsillectomy } & \multirow{3}{*}{28.3} & $\mathrm{~J} 35.3$ & $\begin{array}{c}\text { Clean- } \\
\text { contaminated }\end{array}$ & 2 & 0 & 0 & 2 & & \\
\hline & & J35.9 & Clean & 1 & 0 & 0 & 1 & & \\
\hline & & $\mathrm{J} 35.0$ & Clean & 1 & 0 & 0 & 1 & & \\
\hline $\begin{array}{l}\text { Nasopharyngeal } \\
\text { Angiofibroma }\end{array}$ & 22.60 & D14.0 & Clean & 1 & 1 & 0 & 0 & Cefazoline & \\
\hline $\begin{array}{l}\text { Narcose Excision } \\
\text { Biopsy }\end{array}$ & 21.30 & $\mathrm{C} 30.0$ & Clean & 1 & 0 & 0 & 1 & & \\
\hline \multirow{10}{*}{$\begin{array}{l}\text { Microlaryngeal } \\
\text { Surgery }\end{array}$} & 30.09 & D14.1 & Clean & 1 & 0 & 0 & 1 & & \\
\hline & 31.43 & D14.1 & Clean & 3 & 0 & 0 & 2 & & \\
\hline & & & $\begin{array}{c}\text { Clean- } \\
\text { contaminated }\end{array}$ & 1 & 0 & 0 & 1 & & \\
\hline & & C76.0 & Clean & 1 & 0 & 0 & 1 & & \\
\hline & & $\mathrm{J} 38.4$ & $\begin{array}{c}\text { Clean- } \\
\text { contaminated }\end{array}$ & 1 & 0 & 0 & 1 & & \\
\hline & & D14.1 & Clean & 1 & 0 & 0 & 1 & & \\
\hline & & D14.1 & Clean & 4 & 0 & 0 & 4 & & \\
\hline & & & $\begin{array}{c}\text { Clean- } \\
\text { contaminated }\end{array}$ & 1 & 0 & 0 & 1 & & \\
\hline & & C32.1 & $\begin{array}{c}\text { Clean- } \\
\text { contaminated }\end{array}$ & 1 & 0 & 0 & 1 & & \\
\hline & 30.09 & $\mathrm{~J} 38.0$ & $\begin{array}{c}\text { Clean- } \\
\text { contaminated }\end{array}$ & 1 & 0 & 0 & 1 & & \\
\hline \multirow{4}{*}{ Caldwell-Luc } & 21.22 & D14.0 & Clean & 1 & 0 & 0 & 1 & & \\
\hline & 22.2 & $\mathrm{~J} 32.0$ & $\begin{array}{c}\text { Clean- } \\
\text { contaminated }\end{array}$ & 1 & 1 & 0 & 0 & Cefazoline & \\
\hline & & $\mathrm{J} 32.9$ & $\begin{array}{c}\text { Clean- } \\
\text { contaminated }\end{array}$ & 1 & 1 & 0 & 0 & Cefazoline & \\
\hline & 22.39 & $\mathrm{~J} 33.8$ & Clean & 1 & 1 & 0 & 0 & Cefazoline & \\
\hline $\begin{array}{l}\text { MAE granulation } \\
\text { extraction / } \\
\text { Cholesteatosis }\end{array}$ & 18.29 & H61.9 & $\begin{array}{c}\text { Clean- } \\
\text { contaminated }\end{array}$ & 1 & 0 & 1 & 0 & & Ceftriaxone \\
\hline \multirow{2}{*}{$\begin{array}{l}\text { Esophagoscopy }+ \\
\text { extraction (III) }\end{array}$} & \multirow{2}{*}{42.24} & $\mathrm{~T} 18.1$ & Clean & 1 & 1 & 0 & 0 & Unspecified & \\
\hline & & D13.0 & Clean & 1 & 0 & 0 & 1 & & \\
\hline \multirow{2}{*}{ FESS } & 22.9 & J32.9 & Clean & 1 & 1 & 0 & 0 & Cefazoline & \\
\hline & 22.64 & $\mathrm{~J} 33.8$ & Clean & 1 & 1 & 0 & 0 & Cefazoline & \\
\hline $\begin{array}{l}\text { Hemiglosectomy+ } \\
\text { SOHND }\end{array}$ & 25.2 & $\mathrm{C} 02.1$ & $\begin{array}{c}\text { Clean- } \\
\text { contaminated }\end{array}$ & 1 & 1 & 0 & 0 & Cefazoline & \\
\hline $\begin{array}{l}\text { Grommet Insertion } \\
\text { (III) }\end{array}$ & & H65.3 & Clean & 1 & 0 & 0 & 1 & & \\
\hline $\begin{array}{l}\text { Laryngectomy + } \\
\text { ND }\end{array}$ & 30.4 & $\mathrm{C} 32.0$ & Clean & 1 & 1 & 0 & 0 & Cefazoline & \\
\hline \multirow{3}{*}{$\begin{array}{l}\text { Total Laryngectomy } \\
\text { (III) }\end{array}$} & 30.3 & C32.1 & Clean & 2 & 2 & 0 & 0 & Cefazoline & \\
\hline & 30.4 & C32.9 & Clean & 2 & 1 & 0 & 1 & Cefazoline & \\
\hline & 30.3 & C32.9 & Clean & 1 & 1 & 0 & 0 & Cefazoline & \\
\hline
\end{tabular}




\begin{tabular}{|c|c|c|c|c|c|c|c|c|c|}
\hline \multirow{4}{*}{ Mastoidectomy (III) } & 20.32 & H66.2 & Clean & 1 & 0 & 1 & 0 & & Ceftriaxone \\
\hline & & H66.1 & Clean & 1 & 0 & 1 & 0 & & Ceftriaxone \\
\hline & 18.6 & H66.2 & Clean & 1 & 0 & 0 & 1 & & \\
\hline & 19.53 & H66.1 & Clean & 1 & 0 & 1 & 0 & & Ceftriaxone \\
\hline \multirow{2}{*}{$\begin{array}{l}\text { Radical } \\
\text { Mastoidectomy }\end{array}$} & 19.4 & H66.2 & Clean & 1 & 0 & 0 & 1 & & \\
\hline & 19.55 & H66.1 & Clean & 1 & 1 & 0 & 0 & Cefazoline & \\
\hline $\begin{array}{l}\text { Multiple incisional } \\
\text { biopsy(III) }\end{array}$ & 29.12 & D10.6 & $\begin{array}{c}\text { Clean- } \\
\text { contaminated } \\
\end{array}$ & 1 & 0 & 1 & 0 & & Ceftriaxone \\
\hline \multirow[t]{2}{*}{$\begin{array}{l}\text { Myringoplasty / } \\
\text { Tympanoplasty }\end{array}$} & 19.4 & H66.1 & Clean & 1 & 1 & 0 & 0 & Cefazoline & \\
\hline & 18.6 & H66.2 & Clean & 1 & 0 & 1 & 0 & & Ceftriaxone \\
\hline $\begin{array}{l}\text { Osteoma / exostose } \\
\text { (III) }\end{array}$ & 18.31 & H71 & Clean & 1 & 0 & 1 & 0 & & Ceftriaxone \\
\hline \multirow{6}{*}{$\begin{array}{l}\text { Lateral Rhinotomy } \\
+ \text { Medial Maxillec- } \\
\text { tomy }\end{array}$} & 76.39 & D14.0 & Clean & 1 & 1 & 0 & 0 & Cefazoline & \\
\hline & & D14.0 & Clean & 1 & 1 & 0 & 0 & Cefazoline & \\
\hline & 21.1 & D14.0 & Clean & 1 & 0 & 1 & 0 & & Ceftriaxone \\
\hline & & C 30.0 & $\begin{array}{c}\text { Clean- } \\
\text { contaminated }\end{array}$ & 1 & 1 & 0 & 0 & Cefazoline & \\
\hline & & D14.0 & $\begin{array}{c}\text { Clean- } \\
\text { contaminated }\end{array}$ & 1 & 1 & 0 & 0 & Cefazoline & \\
\hline & 22.62 & D14.0 & $\begin{array}{c}\text { Clean- } \\
\text { contaminated }\end{array}$ & 1 & 1 & 0 & 0 & Cefazoline & \\
\hline \multirow{5}{*}{$\begin{array}{l}\text { Septum Correction } \\
\text { + Turbinectomy }\end{array}$} & 21.1 & D14.0 & Clean & 1 & 1 & 0 & 0 & Cefazoline & \\
\hline & & $\mathrm{J} 34.2$ & Clean & 1 & 0 & 0 & 1 & & \\
\hline & 21.88 & $\mathrm{~J} 34.2$ & Clean & 1 & 1 & 0 & 0 & Cefazoline & \\
\hline & 22.42 & $\mathrm{~J} 32.0$ & $\begin{array}{c}\text { Clean- } \\
\text { contaminated }\end{array}$ & 1 & 0 & 0 & 1 & & \\
\hline & 21.88 & $\mathrm{~J} 34.2$ & Clean & 1 & 0 & 0 & 1 & & \\
\hline $\begin{array}{l}\text { Subtotal lobectomy } \\
\text { (III) }\end{array}$ & 06.39 & $\mathrm{C} 73$ & Clean & 1 & 1 & 0 & 0 & Cefazoline & \\
\hline $\begin{array}{l}\text { Subtotal thyroidec- } \\
\text { tomy/ total thyroid } \\
\text { nodules }\end{array}$ & 06.39 & $\mathrm{C} 73$ & Clean & 1 & 1 & 0 & 0 & Cefazoline & \\
\hline \multirow{6}{*}{ Tracheostomi } & 29.12 & C11.9 & Clean & 1 & 1 & 0 & 0 & Cefazoline & \\
\hline & & C83.7 & Clean & 1 & 1 & 0 & 0 & Cefazoline & \\
\hline & & C32.9 & Clean & 1 & 1 & 0 & 0 & Cefazoline & \\
\hline & & J95.0 & Clean & 1 & 1 & 0 & 0 & Cefazoline & \\
\hline & & D14.1 & Clean & 2 & 2 & 0 & 0 & Cefazoline & \\
\hline & 31.75 & J38.6 & Clean & 1 & 0 & 0 & 1 & & \\
\hline
\end{tabular}

\section{Discussion}

Our result shows higher number of male patients. In the previous study, gender did not have a definitive effect on the rate of surgical site infections. ${ }^{12}$ Here, we found a different age range from previous studies because this study used a different age group range. ${ }^{13}$ A previous study showed that age, low-level of albumin serum , and quality of surgical technique are the most important patient-related factors and procedure-related factor respectively; Moreover, patient-related factors are more likely to develop SSIs than procedure-related factors. ${ }^{14}$

The pattern of the use of preoperative antibiotics is quite diverse and heterogeneous. Based on Table 3, the use of preoperative antibiotics was influenced by procedures, even with different ICD CM 9 codes. This result confirms previous study, stated SSIs are very diverse and heterogeneous, varies greatly depends on procedures, patients, surgeons, and hospitals.

Based on existing literature, antibiotics are specifically indicated for biopsies or incisions in contaminated or infected sites. ${ }^{15}$ Several operative procedures, such as adenotonsillectomy, narcose excision biopsy, microlaryngeal surgery, insertion of the grommet (III), and Caldwell-Luc, prophylactic antibiotic is not indicated.11 However, this study revealed antibiotics were given for Caldwell-Luc procedure with chronic maxillary sinusitis 
(J32.0), chronic sinusitis, unspecified (J32.9), and other polyp of sinus (J33.8), since antibiotics were effective treating chronic sinusitis.16 This shows that antibiotic usage are also influenced by current medical conditions.

In other surgical intervention, antibiotic prophylaxis should be given.11 Based on the data, several surgical intervention such as MAE granulation extraction/ cholesteatosis, esophagoscopy+extraction (III), FESS (Functional Endoscopic Sinus Surgery), total laryngectomy (III), mastoidectomy (III), myringoplasty/ tympanoplasty, osteoma/exostoses (III), lateral rinotomy + medial maxillectomy, septum correction + turbinectomy, subtotal lobectomy (III), and tracheostomy were given prophylactic antibiotic. Prophylactic antibiotic should be given approximately 30 minutes before making the incision and for 24 hours after surgery. Broad spectrum antibiotics are used for covering the aerobic and anaerobic bacterial flora of the nasal and oral cavities. Intraoperative topical antibiotic irrigation of the surgical field greatly reduces postoperative infections. ${ }^{11}$ If the patients are not using any antibiotics, they must be administered during the induction of anesthesia and continued for a minimum of 24 hours. ${ }^{11}$ This administration of antibiotics may prevents Pseudomonal and Staphylococcal species to cause any SSIs. ${ }^{17}$ Based on multiple randomized controlled trials, perioperative antibiotics for procedures involving esophageal and gastrointestinal tract showed promising benefits in prevention of SSIs. ${ }^{18}$ A single dose of long halflife antibiotic can greatly reduce the risk of any SSIs in patients underwent major surgery for esophageal cancer. ${ }^{19}$

In this study, several surgical intervention do not use antibiotic due to different reason. MAE granulation extraction/cholesteatosis, esophagoscopy + extraction (III) with diagnosis code D13.0, mastoidectomy (III), multiple biopsy incision (III), myringoplasty/tympanoplasty with the ICD9 CM code 18.6, and one lateral rinotomy + medial maxillectomy case because the patient had been given previous therapeutic antibiotics. Ceftriaxone can be considered for initial intervention of severe patients with unknown infection when gram-negative aerobes (other than Pseudomonas spp.) are suspected or patients with suspected antibiotics resistance. ${ }^{20}$

According to FESS (Functional Endoscopic Sinus Surgery), prophylactic antibiotic use is indicated. There are less prominent evidences to support the IV antibiotics for prophylactic in FESS. ${ }^{11}$ However, this practice of IV prophylactic antibiotic is common. ${ }^{21}$

In this study, total laryngectomy (III) operation with ICD 9 CM code 30.4 (radical laryngectomy) and diagnosis code C32.9 (larynx ca) and total mastoidectomy (III) operation with a diagnosis of severe CSOM dextra prophylactic, antibiotic should be indicated. However, prophylactic or therapeutic antibiotics were not given. This might be occured because of incomplete operation reports or human error.

Our data demonstrated the most widely used prophylactic antibiotic was cefazoline. IV of 1000 - 2000 $\mathrm{mg}$ Cefazoline is recommended as a prophylactic antibiotic for clean and clean-contaminated otorhinolaryngologyhead and neck surgery at Dr. Soetomo General Hospital Surabaya with. ${ }^{22}$ Cefazoline is a drug of choice for prophylaxis, because its promising broad-spectrum antimicrobial activity. Cefazoline has an extensive duration of action, inexpensive, and covers organisms that often complicate surgery. ${ }^{23}$ Ceftriaxone appears efficacious in the prevention of postoperative infections following some types of surgery. Despite its convenience of a single preoperative dose, there were no convincing advantages have been demonstrated over the 'first' and 'second generation' cephalosporins; ceftriaxone has a better antimicrobial profile than cefazoline, especially for multiresistant strains, yet prophylaxis is directed at non-multiresistant organisms. ${ }^{20}$ The use of antibiotics must consider several factors, including microorganism resistance, pharmacokinetic and dynamic factors, interaction factors and drug side effects, and cost factors. ${ }^{8}$ Therefore, it is important for medical personnel to use antibiotics efficiently.

\section{Conclusion}

Most of the otorhinolaryngology surgeries performed in Dr. Soetomo General Hospital Surabaya from December 2017 to January 2018 were clean surgeries. Perioperative antibiotics usage in most operations were consistent with existing literature. The most widely used prophylactic antibiotic was cefazoline, while the most therapeutic antibiotic was ceftriaxone. Further research about risk factor of surgical site infection, the use of antibiotic prophylaxis, and bacterial profile with more samples is needed for more accurate results.

\section{Conflict of Interest}

The author would like to declare that there is no conflict of interest in conducting this study.

\section{References}

1. Nichols RL. Preventing Surgical Site Infections : A Surgeon's Perspective. 2001; 7: 220-224.

2. Owens CD, Stoessel K. Surgical site infections : epidemiology, microbiology and prevention. J Hosp Infect 2008; 70: 3-10.

3. WHO. Prevention of hospital-acquired infections World Health Organization.

4. Yuwono. Pengaruh Beberapa Faktor Risiko Terhadap Kejadian Surgical Site Infection ( SSI ) Pada Pasien Laparotomi Emergensi. 2013; 15-25.

5. Marsanto AE, Paraton H, Prasetyo B. Pattern of disease and type of operation of Surgical Site Infection in obstetrics and gynecology at Dr Soetomo Hospital, Surabaya, Indonesia. 2019; 27: 49-55.

6. Larson EL, Pearson ML, Lee JT, et al. Guideline For Prevention Of Surgical Site, 1999.

7. National Collaborating Centre for Women's and Children's Health. Surgical site infection prevention and treatment of. 2008.

8. Indonesia MKR. Peraturan Menteri Kesehatan Republik Indonesia Nomor 2406/MENKES/PER/XII/2011. 2011.

9. Centers for Disease Control and Prevention. Antibiotic Resistance Threats in the United States, 2019.

10. Kijima T, Masuda H, Yoshida S, et al. Antimicrobial Prophylaxis is Not Necessary in Clean Category Minimally Invasive Surgery for Renal and Adrenal Tumors: A Prospective Study of 373 Consecutive Patients. URL 2012; 80: 570-575.

11. Myers E, Snyderman C. Operative Otolaryngology Head and Neck Surgery. Elsevier Health Sciences, 2018.

12. Johannes S, Aghdassi S, Schröder C, et al. Gender-related risk factors for surgical site infections. Results from 10 years of surveillance in Germany. 2019; 1-8.

13. Sommer M. Prevalence and Predictors of Postoperative Pain After Ear, Nose, and Throat Surgery. 2015; 135: 124-130.

14. Dominioni L, Imperatori A, Rotolo N, et al. Risk Factors for Surgical Infections. 2006; 7: 9-13.

15. University of IOWA Health Care. Microdirect Laryngoscopy 
(Suspension Microlaryngoscopy or Direct Laryngoscopy), https:// medicine.uiowa.edu/iowaprotocols/microdirect-laryngoscopysuspension-microlaryngoscopy-or-direct-laryngoscopy (2018, accessed 10 September 2019).

16. Gandhi A, Brodsky L, Ballow M. Benefits of Antibiotic Prophylaxis in Children with Chronic Sinusitis : Assessment of Outcome Predictors. 2016; 37-43.

17. Pierce NE, Antonelli PJ. Efficacy of Antibiotic Prophylaxis Prior to Tympanoplasty for Contaminated Cholesteatoma. 2016; 1-4.

18. Stephanie H C, Alexander S. K. Perioperative Antibiotics in Thoracic Surgery Stephanie. 2013; 22: 35-45.

19. Ruol A, Bertiato G, Boscarino S, et al. Short-Term Prophylaxis with Ceftriaxone Plus Metronidazole in Esophageal Cancer Surgery Short-Term Prophylaxis with Ceftriaxone Plus Metronidazole in
Esophageal Cancer Surgery. 9478. Epub ahead of print 2017. DOI: 10.1080/1120009X.2000.11782304.

20. Richards DM, Heel RC, Brogden RN, et al. Ceftriaxone A Review of its Antibacterial Activity, Pharmacological Properties and Therapeutic Use. 1984; 527: 469-527.

21. Chandra RK, Conley DB, Kern RC. Prophylactic i.v. antibiotics in functional endoscopic sinus surgery: Trends and attitudes of the American Rhinologic Society membership. 2016; 23: 448-450.

22. Amri G, Matulatan F, Widodo A. Profil Penggunaan Antibiotik Pada Kasus Bedah Di IRD Rsud Dr. Soetomo Surabaya.

23. ASHP, IDSA, SIS, et al. Clinical Practice Guidelines for Antimicrobial Prophylaxis in Surgery. In: ASHP Therapeutic Guidelines. 2013. 